\title{
WEAVING THE PAST IN A FABRIC: OLD BELIEVERS' TRADITIONAL COSTUME
}

\section{Cristina Clopot}

\begin{abstract}
Costume plays an important part in expressing ethnic identity. This article develops an analysis of the Old Believers' traditional costume in its current usage. To differentiate between various uses for such material items, the article considers their active use, embedded in rituals and ceremonial life, and a passive use, as exhibits in a museum. The ethnic costume is still preserved in the community for religious rituals. Older cuts and materials are used for costumes worn by choir groups in their performances at social and cultural events to represent their identity. The evolution and modernisation of the different costume pieces today are considered through examples drawn from my ethnographic research with Old Believers' communities in Romania.
\end{abstract}

Keywords: costume, ethnicity, heritage, identity, meta-cultural productions, Old Believers, Romania

\section{INTRODUCTION}

It was January 7, 2015, and Old Believers across Romania were celebrating Christmas according to the Julian calendar. My partner and I were in the northern part of Romania, sitting at the Christmas table with representatives of three generations of Old Believers. While enjoying traditional Russian dishes customary for this celebration, we were discussing different topics, sharing memories and experiences. Prolonged discussions were encouraged by the fact that this holy day, like all holy days, came with a prohibition to work - a rule usually respected in the community. Among talk about suitable recipes, traditions, and the future of the community, the discussion then took a turn back to the 1989 revolution and the changes it had brought about. The revolution marked the end of the 45 years of communist rule and the beginning of democracy in Romania, a process which generated significant changes in all walks of life. Anton ${ }^{1}$, one of my informants, started telling a story about an Old Believer living in the northern side of the country. Lake Fălticeni, now at the border of the homonymous city, was created artificially during the communist period. Some time after the revolution, an Old Believer from a nearby village, who 
had a piece of land near the lake, came to work on his land and saw people sunbathing, in skimpy bathing suits. He was dressed in a traditional manner, with a rubashka (long-sleeved shirt without a collar) and a poias (handmade belt), in the sizzling 40-degree summer sun. People were standing there in swimsuits. Anton said: "He crossed himself - the apocalypse had arrived; he had never seen such a thing". We all laughed. As Anton further explained, Old Believers lived in secluded villages and they rarely met other people. It was thus quite a shock for this conservative Old Believer to see these people, especially in such a state of undress.

This is just a glimpse into the numerous discussions I have had with different Old Believers during my fieldwork, but it helps to set the tone for this article. The mismatch between globalised mainstream population and the conservative Old Believers' imaginary speaks for some of the ideas discussed here. As Daniel Miller writes in his book Stuff, "the concept of the person, the sense of the self, the experience of being an individual, are radically different at different times and in different places, partly in relation to differences in clothing" (Miller 2010: 40).

The analysis presents some of the findings from an extensive doctoral research conducted in Romania as a multi-sited ethnographic study. The fieldwork was carried out during 2014-2015, following the 'yo-yo' method (Wulff 2002), which included participant observation and interviews as main research methods. The sites covered in my research included villages in Moldavia (Focuri, Manolea, Fălticeni, Târgu Frumos) and Dobruja (Jurilovca, Slava Rusa, Tulcea).

Before starting the analysis of these material expressions, a short review of this ethnic group's history is necessary to set the context of this discussion and understand the current living circumstances and the attitudes of Old Believers towards materiality.

\section{THE HISTORY OF THE OLD BELIEF}

The timeline of events relevant to Old Believers starts somewhere at the end of the 16th century, a time historians refer to as the Time of Troubles (Pascal 1963). It was the era when the developing Russia got into a systemic crisis followed by several waves of invasion of Polish and Sweden forces as well as internal rebellions, famine, and mass death. A movement for religious and moral redemption of the once glorious Russian state was started, with an aim of establishing Russia as the 'Third Rome' (Druzhelyubov 2007). Discrepancies appeared between the way people saw Christianity and the manner in which the Church understood it. At a political level, a movement of political centrali- 
sation and subordination of the Church to the Monarchy was the primary aim of the monarchs. The aim of religious and administrative leaders was to align church books and Orthodox practices with the Byzantine ones.

Later, in 1654, the Council of the Russian Orthodox Church convened, and Tsar Alexey Mikhailovich and Patriarch Nikon of Moscow and all the Rus' formally presented the changes proposed. Apart from revisions of the liturgical books, Nikon's reforms included ritual changes (Druzhelyubov 2007). These efforts were resisted by the conservative opposition, who considered that these changes altered the 'pure' form of Orthodoxy that had been practised in Russia since the introduction of Christianity in the 10th century.

A countermovement was thus set in motion whilst the authorities pushed forward the reforms. Key years in this timeline were 1666-1667, when the old books were formally interdicted, and after this moment the Old Believers were considered heretics (Meyendorff 1991). A system of punishments and fines was imposed on those who continued to practise the former beliefs. In an effort to preserve their old way of life, the Old Believers moved towards the periphery of the Russian land and beyond.

Old Believers' response to these innovations was not unanimous, however. Different views on reforms drove people to form several groups. Although they adopted diverse stances, they all shared the ground belief that these innovations were not welcome. The two major groups that appeared are called Popovtsy and Bespopovtsy. The groups in the former category recognised priests as leaders of their community, while the latter were priestless. Among the priestless communities, some took a radical stance against innovation. Believing that the world was taken over by Antichrist and no order can be recognised any longer, they engaged in mass suicide, believing fire would purify their soul. The Bespopovtsy branch was not uniform though; these people were separated into different small communities such as Pomortsy, Fedoseevtsy, Filippovtsy, and others.

As a result of these turbulent times, and in an effort to carry on their way of life and observe their religious beliefs, Old Believers migrated to the periphery of the Russian Empire, or left Russia altogether, spreading across the world. Today Old Believer communities can be found in Estonia, Latvia, Lithuania, Romania, and Bulgaria, but also outside Europe in countries such as Canada, the United States, and Australia.

Old Belief was not accepted officially for a long time. It was only in 1905 that the last Russian tsar issued an edict of toleration, which included Old Belief.

Throughout the 18th century into the beginning of the 19th century, Old Believers migrated to the current territory of Romania, which at that time was divided between the Austro-Hungarian and Ottoman Empires (Prygarine 2004). A discerning note needs to be made here for the Nekrasov Cossacks from 
the Don area, which researchers place in the Dobruja area (Fenoghen 1998; Fenoghen \& Fenoghen 2004). Prygarine (2004) mentions Vetka and Starodub surroundings as a starting and transfer point of migrations, with 1820-1830 marked as a peak in migration. Ipatiov (2001) also indicates Vetka, Don, and Kuban as centres gathering Old Believers from a wider area that includes Moscow and its surroundings (Kostroma, Vladimir) as well as Orel, Voronezh, and Saratov.

According to the latest census, there are about 23,000 Old Believers today in Romania, which is one of the smaller ethnic groups in this multicultural country. The Hungarian ethnic community, by comparison, is formed by 1,238,000 people, who live throughout the country. The largest communities of Old Believers are concentrated in Moldavia (north-eastern area of the country) and the Danube Delta (the south-east).

\section{CLOTHING AND IDENTITY}

Researchers have often signalled a link between clothing, ethnic identity, and heritage. As reflected in the short historical overview, strong links are drawn between identity and religion for Old Believers, echoing Bhikhu Parekh's argument that "their religious identity constitutes the axis of their lives and provides the overarching framework within which they define and relate their other identities" (Parekh 2007: 133). Old Believers' spirituality also guides their appreciation of style. Style, as Webb Keane argues, "allows one to recognize, across indefinitely many further occasions, instances of 'the same thing"' (Keane 2005: 196).

Intricate, multi-layered, at times fragmented heritage processes are accommodated within a community. As Kristin Kuutma (2013: 6-7) argues, "This reflects the complexities of how communities define and negotiate memory and identity, how they communicate and engage with each other".

Consequently, it does not come as a surprise that the costume is also entangled in different processes at the same time. Firstly, I would note there is a passive use of costume: it stands to represent ethnic identity as tangible cultural heritage. Clothing items are presented as artefacts included in museums across Romania or in other countries with Old Believers' communities such as Estonia (the Old Believers' museum in Kolkja). They stand, as Antonio Arantes describes them, as "meta-cultural realities; in other words, they become official representations of current representations and practices" (Arantes 2013: 40). As representations of Old Believer identity they are disengaged from the social 
Figure 1. Lestovka, Old Believer rosary. Photograph by Cristina Clopot, Moldavia area, June 2014.

life. They come to represent what Barbara Kirshenblatt-Gimblett describes as "the obsolete, the mistaken, the outmoded, the dead, and the defunct" (Kirshenblatt-Gimblett 1995: 369). "Exhibition endows heritage thus conceived with a second life"

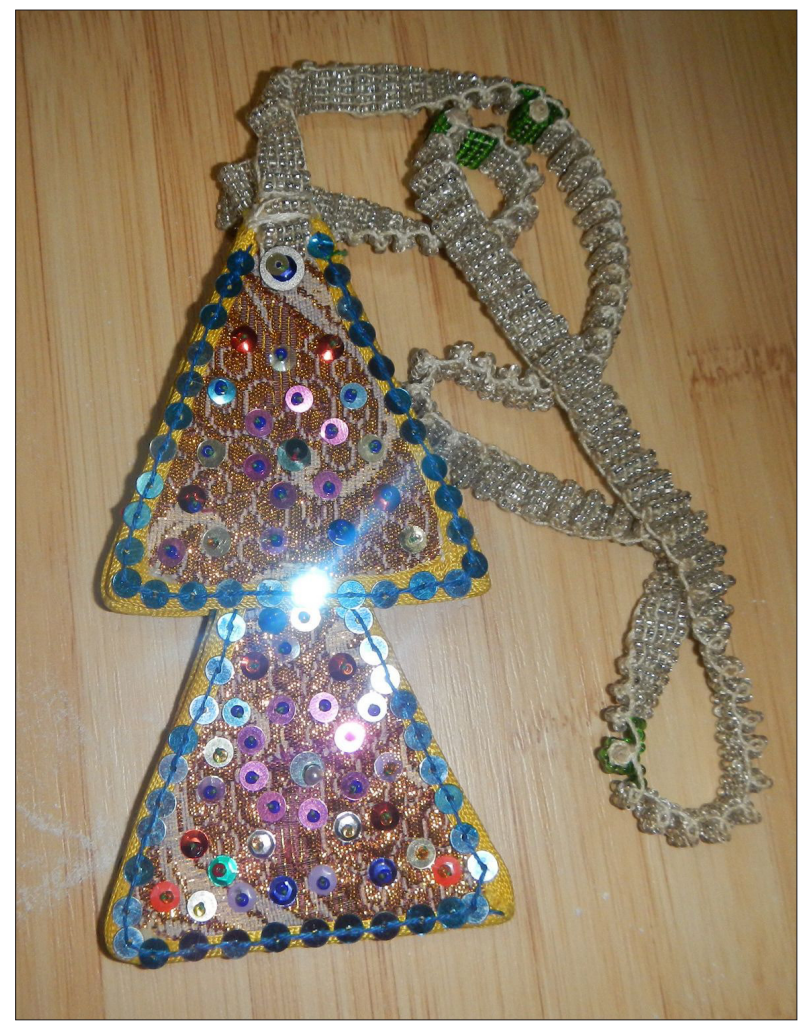
(ibid.).

Costumes serve an active role within the community, when they are embedded in existing social practices. In this sense, they represent a tradition being carried forward along the lines of the definition of intangible cultural heritage (ICH). As Article 2 of the 2003 UNESCO Convention mentions, "this intangible cultural heritage, transmitted from generation to generation, is constantly recreated by communities and groups in response to their environment, their interaction with nature and their history, and provides them with a sense of identity and continuity" (UNESCO 2003).

The different elements of costumes, both for men and women, are usually handmade. An example is the poias, the woven belt worn by Old Believers after they are baptised. Artisans in different communities crochet or weave these belts on improvised looms, then sell them at church or in their village. Sometimes, skilled artisans become known throughout Romania and can receive orders from across the country.

A further element to be considered here, linked with traditional crafts understood under the umbrella of the ICH, is the lestovka, the rosary. This ethno- 
confessional symbol has powerful symbolic properties and Old Believers take it with them for church masses (Fig. 1). Every element of this object, from the larger triangles to the smaller beads, is symbolic. Each corner of the triangles stands for an evangelist, the first larger node on the string counts the time that Christ has spent in the Virgin's womb, the next thirty-three for the number of years spent on earth, while the last seventeen stand for the seventeen prophets that announced his coming. There are two varieties of lestovka currently available, one made from artificial crocheted beads, another made of genuine or faux leather. In the main, the former seems to be the one preferred in Romania; the genuine leather ones found during fieldwork were either gifts from outside the country, or kept from long ago.

In the next section I will mainly focus on the active role of costume within the Old Believers' community, although parallels with museum displays will be drawn from time to time to illustrate shifts in meaning or representation.

\section{SEMIOTICS AND CLOTHING}

The ideas in this paper draw, partially, from Webb Keane's development of Charles Pierce's semiotics (Keane 2003, 2005a). As Keane argues, interpretation depends on the context, linked with the social imaginary, to categorise what is deemed an appropriate feature for an object. Keane uses the idea of a 'semiotic ideology', which he describes as "people's background assumptions about what signs are and how they function in the world" (Keane 2003: 419). Old Believers' semiotic ideologies are rooted in their inheritance - the rules and regulations their ancestors observed in Russia.

Yet, such systems are not stable, unchanging constructs. The openness of significations means that, as Keane (2005a: 190) argues, "objects bring the potential for new realizations into new historical contexts". While this openness represents a threat to existing semiotic ideologies, Keane emphasises the relative stability of the former. Moreover, he argues for a social analysis of objects, not only objects themselves. "We must be attentive to the ways in which they are (for the time being) regimented and brought into relation to other things - much of this being the task of social power" (Keane 2005a: 193). Old Believers' current semiotic ideologies are also in transformation in Romania today and, as outlined further later in the essay, new realisations appear. Can these be interpreted as shifts in acceptable norms or are they more likely to be interpreted as 'invented traditions' (Hobsbawm 1992)? 


\section{RELIGIOUS COSTUME}

Costume is acknowledged here as a semiotic channel between the material and spiritual self. Materiality is not a simple matter of describing the object; for instance, it offers glimpses into Old Believers' religious imaginary, bringing to light the value of purity. As such it offers insights into the "particular associations between visible and invisible, presence and absence, and making people's relationship with the divine immanent and intimate" (Naumescu 2011: 11). Clothing is linked with moral norms; following Keane's ideas, "the ways in which people handle and value material goods may be implicated in how they interpret words, and vice versa... Their treatment of things and words both reflect certain underlying assumptions about the world and the beings that inhabit it" (Keane 2005b: 4). The cautious examples he offers in changing of clothes as signifying more than changes of identity might be reflected for Old Believers too, as changes in clothing are sometimes associated with innovations in rituals and seen as problematic to continuity. Following Keane, again "this cluster of habits, expectations, and constrained possibilities is the outcome of several operations of semiotic regimentation and stabilization" (ibid.: 11).

The elements of an Old Believer woman's religious costume encountered during fieldwork varied, based on the area in which they originated. In Dobruja area, I encountered both two-piece suits, with a shirt and a skirt, iubka, as well as long dresses with or without straps, whitch they addressed as shubka. The dresses with straps, seen in villages in Dobruja, have a high waist, resembling the Dunaiki shubka or talichka models described by Patricia Johnson (1983) in her study of American Old Believers. Costumes are often crafted with bright colours and elaborate patterns for both the shirt and kerchief. Ipatiov (2001) notes that the use of vivid colours relates to life's joys. At times, the skirt would have one or two lines of lace sewn across the lower part. Some informants from the southern part of the country indicated the number was different for married and unmarried women, but informants from the northern side of the country had no knowledge thereof (see Fig. 2). ${ }^{2}$

In other villages there was a preference for a custom-made long wide skirt and a blouse. For head coverings, the two main elements encountered during fieldwork included the kichka and sbornik, which act as signs that a woman is married. The manner in which the sbornik is made differs from one side of the country to the other. The models observed from Dobruja resembled a small cap, to be placed over a loop of hair at the back. The models observed in the northern side of the country covered a greater proportion of a woman's head, 


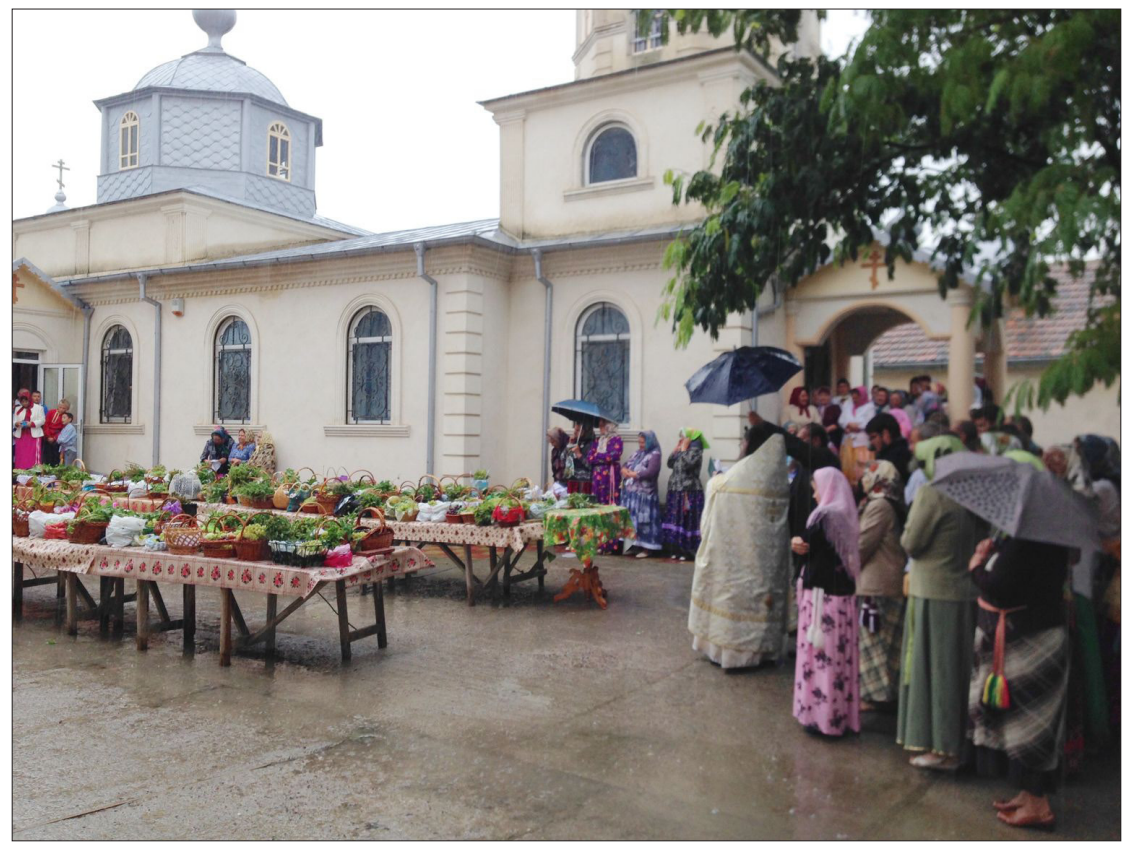

Figure 2. Old Believers during the Easter service when the priest blesses the Easter bread pasca and dyed eggs. Photograph by Cristina Clopot, Moldavia area, May 2015.

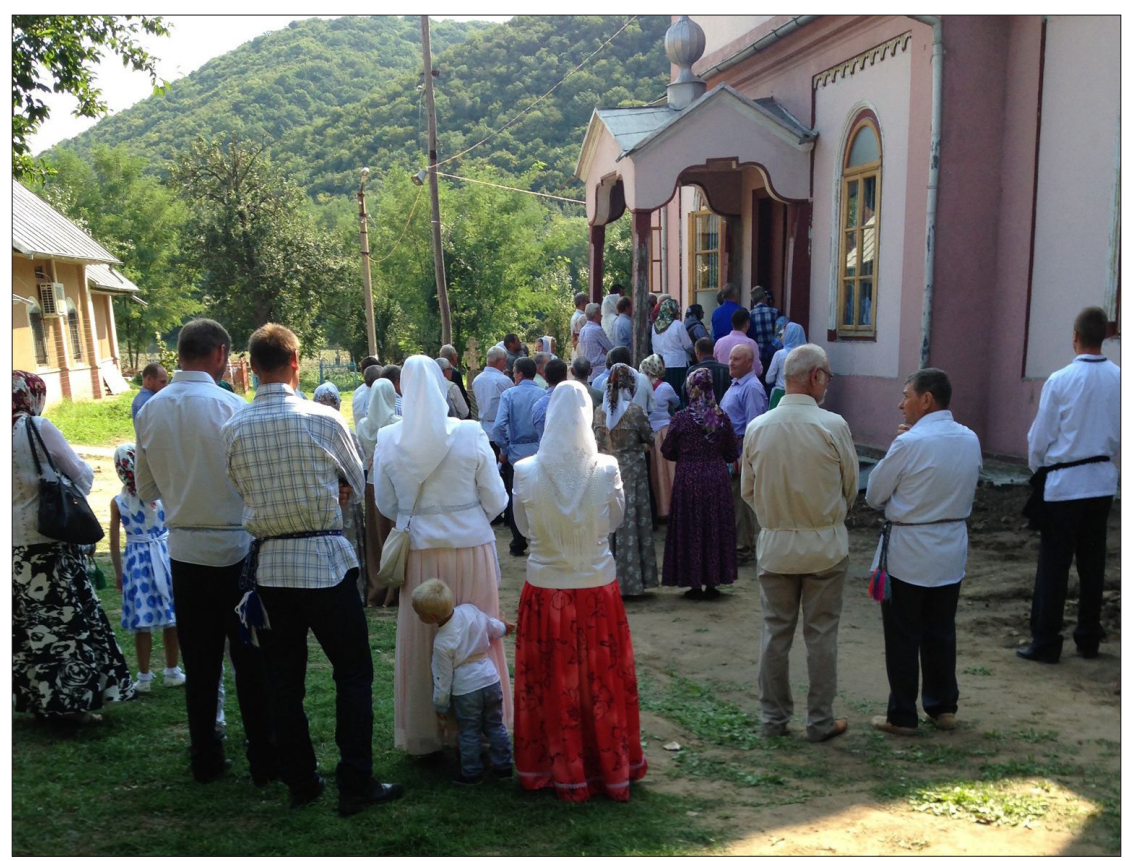

Figure 3. Old Believers in religious costumes gathered for St. Mary's celebration. Photograph by Cristina Clopot, Tulcea County, August 2015. 
resembling a bonnet. These elements can be stitched or adorned with different beads, based on the capacities of the artisans. The kichka is an additional bonnet, simpler in conformation, placed on a woman's head at the marriage ceremony for the first time.

A special type of kerchief mentioned during fieldwork was the kosynka, described by Johnson (1983) as kasyak. Similar to the data she presents, my informants have indicated that the three folds of this plain scarf symbolise the Holy Trinity. However, most often, Old Believers would wear a colourful kerchief to cover their head, often coordinated with the colour of the costume. Such kerchiefs are usually part of a woman's inheritance, and women informants indicate that they own even 50-100 kerchiefs, once worn by their mothers or grandmothers.

For men, the specific elements are the rubashka, the long sleeved shirt with a low collar, the woven belt, and pants. Men are not allowed to cover their head in church. During fieldwork I noticed that some people in certain situations do not wear these types of clothes, which need to be custom-made (Fig. 3), but dress in modern clothes as long as they respect the length rules, pointing to some shifts in what is deemed appropriate attire in the Old Believers' semiotic ideology. In terms of geographic differences, informants indicated that while in the northern part of the country the rubashka can be embroidered anywhere on the fabric, in Dobruja it would only have embroidery elements on the collar or the cuffs.

A further element mentioned during research was the poddevka, a long black coat resembling the kaftan. This is rarely used by common people today, but still worn to church by people who read during the services, as well as deacons and priests.

Yet, while skirts and shirts and trousers might not follow the old patterns, the presence of the woven belt, poias, is a constant (Fig. 4). Linked with the symbolic separation of good and bad within the body in the Old Believers' imaginary, it is considered an essential marker of the Old Believer identity. The poias is the only clothing item which I was not allowed to wear, as I was not christened in the Old Belief tradition. These belts are handmade by local artisans, usually with the help of an improvised loom. Colours vary upon preference; usually the colours chosen are very bright. In the northern part of the country, in villages in Suceava and Iasi counties, informants indicated that, for weddings, the poias needed to be white.

An interesting discovery during fieldwork was that for a person's death, a long white shirt was prepared. The cloth that would cover a dead person's body used to be hand-sewn, without any knots (Liashchenko \& Khriukina 2006). My informants resembled this burial item with a shroud. The semiotics 


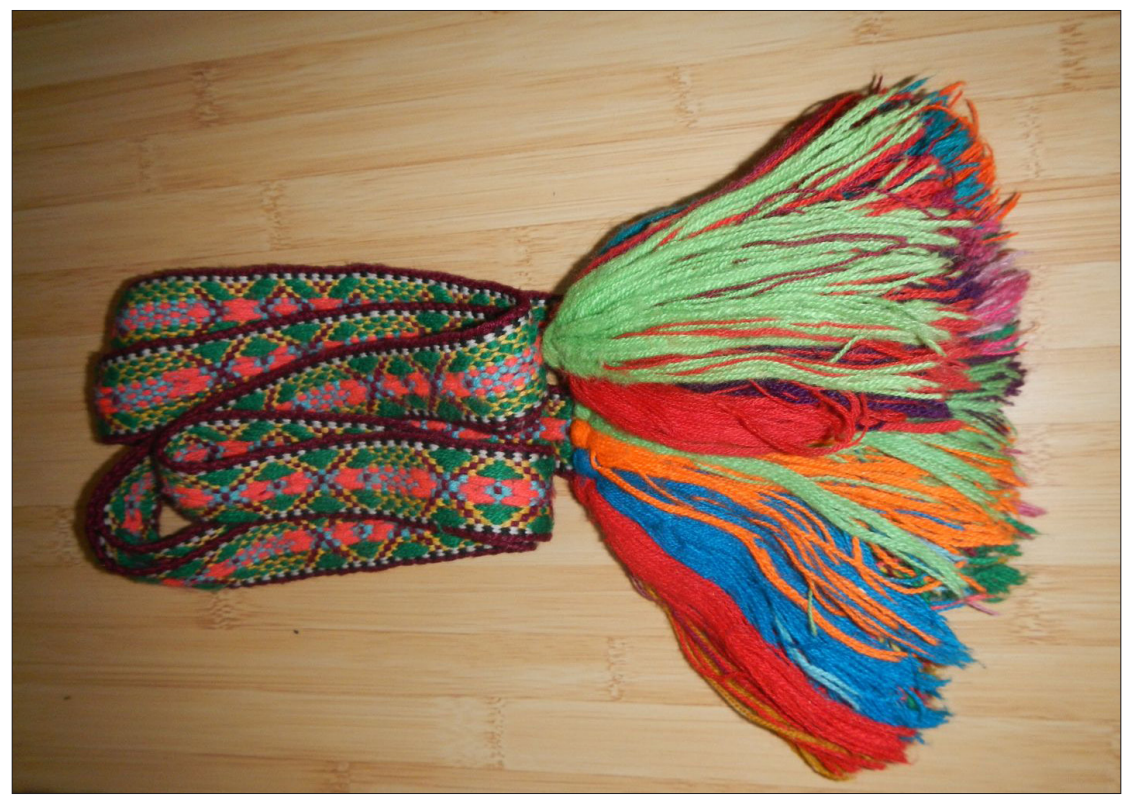

Figure 4. The traditional belt, poias, worn both by women and men. Photograph by Cristina Clopot, Moldavia area, June 2014.

of death for Old Believers is a complicated subject and its consideration is not possible in this limited space. The key idea that bears relevance to my analysis here is the consideration given not only to the objects themselves but also to their production to reflect spiritual processes.

As Juha Pentikäinen (1999: 25) argued about Old Believers in Estonia, "a costume is as sacred as one's soul, which cannot be sold or given to another person outside the family". In this sense the close link between a person and their clothes was revealed by the ritual of burning their clothes after their death, a practice which seems to be less popular today as clothes are instead offered as alms to other persons.

Moreover, the artisans I have spoken with have also emphasised the link with spirituality in the fabrication of both the poias and the lestovka. These objects are considered religious items, and during their production the craftsperson is supposed to continuously pray. The diminishing numbers of craftspeople in Old Believers' communities result in difficulties in procuring these religious objects, and people sometimes order them from hundreds of kilometres away. At bigger celebrations, such as the one portrayed in Figure 3, women brought such objects to sell at dedicated tables set in the church courtyard. Other people 
also informed me that the church would be an appropriate site to order such an item or simply buy one.

To this day, Old Believers hold clothes designated for going to church separate from the rest of their wardrobe. Clearly delimitating the secular from the sacred, an Old Believer would wear selected items only to church. Other sets of similar clothes can be worn in everyday lives, but they become impure and are not deemed appropriate to be worn to church. A person's purity of the soul should be mirrored in materiality as well.

\section{WEDDING COSTUME}

An important rite of passage, in the sense documented by Arnold van Gennep (1996) and Victor Turner (1969), is the wedding. Materiality in this case plays an important role to signify the status change for the female Old Believer through accessories (Figs. 5-6). During the religious wedding ceremony, the service is stopped, the bride is unveiled, her hair is braided and a kichka (a white bonnet, symbol of a married woman) (Fig. 7) and a sbornik (a second bonnet) are placed on her head, followed by a white kerchief. The kerchief with its three corners symbolises the Holy Trinity. From this moment on the woman is supposed to cover her head at all times. In reality, however, such accessories are noticed only when going to church in the northern part of the country and more regularly for celebrations in the southern part of the country. The only women who seem to diligently follow these principles are priests' wives, who cover their heads both in public and private spaces.

As portrayed in Figure 5, Old Believers have come a long way from the old wedding costumes. This was the case with the wedding I attended in Manolea, a small Old Believers' village in the northern part of Romania, in the summer of 2014. The bride's attire did not conform to Old Believers' traditional costume with a skirt and a long-sleeved coat; it was a modern wedding dress and following the above-mentioned rules she covered her arms with a silky bolero. Yet, the traditional accessories were also present here - the poias and the lestovka, the rosary. Her attire did not meet consensus, however, and an older Old Believer woman asked her prior to leaving home whether such innovations were acceptable. The bride jokingly resolved the situation saying that "if [the priest] says something I'll tell him I couldn't afford more material".

This example adds another thread to the debate between modernity and tradition. How are such issues settled? Before going into these arguments I will briefly look at a third example of costume use. 


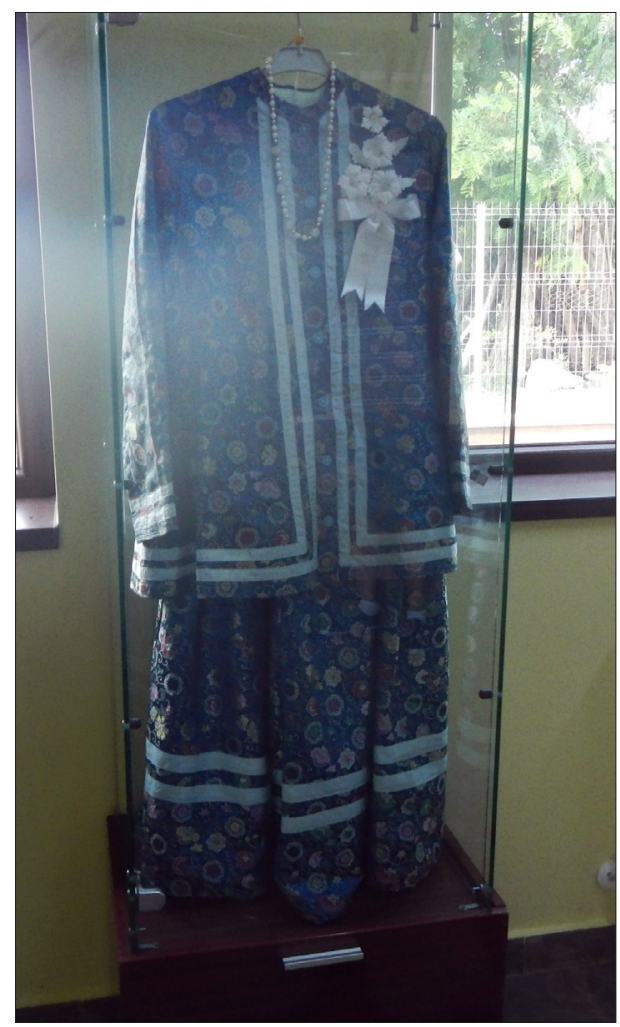

Figures 5-6. Wedding costumes old and new. Photographs by Cristina Clopot, Moldavia area, July 2015.

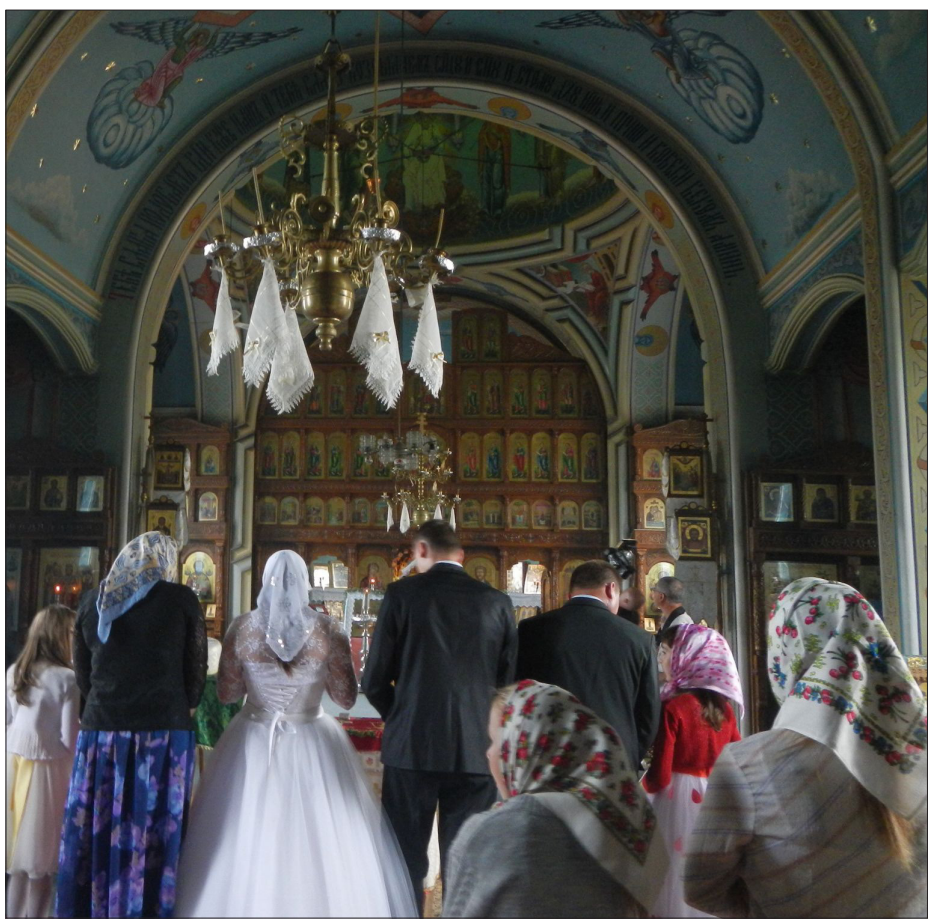




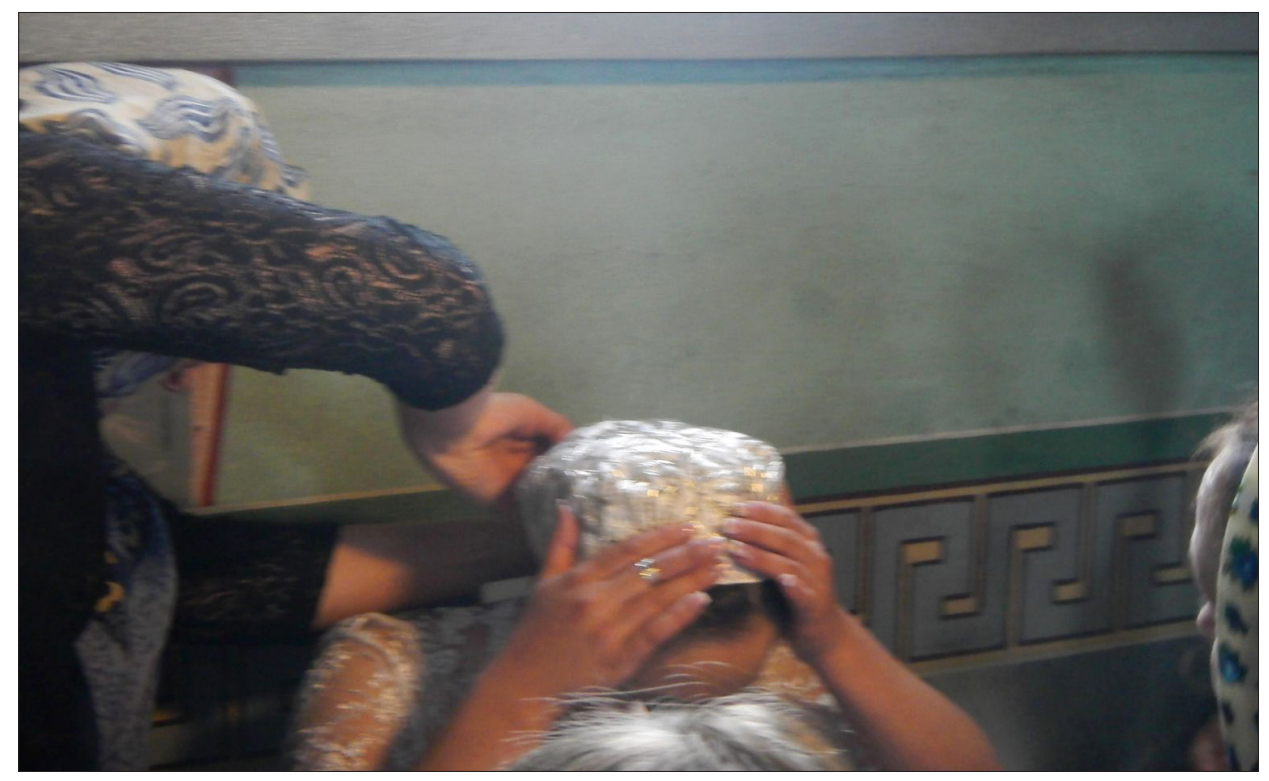

Figure 7. Putting the kichka on during a wedding ceremony. Photograph by Cristina Clopot, Moldavia area, July 2015.

\section{SECULAR COSTUMES AND INVENTED TRADITIONS}

Ipatiov (2001) indicates the traditional secular celebration costume for Old Believers included a sarafan type of dress. With some variations in cut across the country, this long dress was commonplace. Such costumes, however, are rarely seen in Old Believers' communities today. Yet, with the efforts made to reclaim their heritage following the post-communist period, Old Believers have revived a costume which they refer to as sarafan for choirs or dancing groups across the country. Putting forward claims to authenticity, such groups use these items as markers of Old Believer identities. These costumes, however, are made on the basis of a stereotypical version of the Russian costume generalising and simplifying different elements and as such are reconstructions of dresses perceived as Russian to display ethnic identity on stage (Figs. 8-9). At times, choir groups opt to have two-piece costumes, with a long skirt and a blouse, sometimes made of taffeta or velvet. When asked about these elements, informants' narratives often argue that as these costumes were designed in the style of original models, they could be considered traditional. They are also used to reflect Russian ethnic identity when such groups are called to entertain tourists or promote their ethnic heritage in minority groups' special events, 


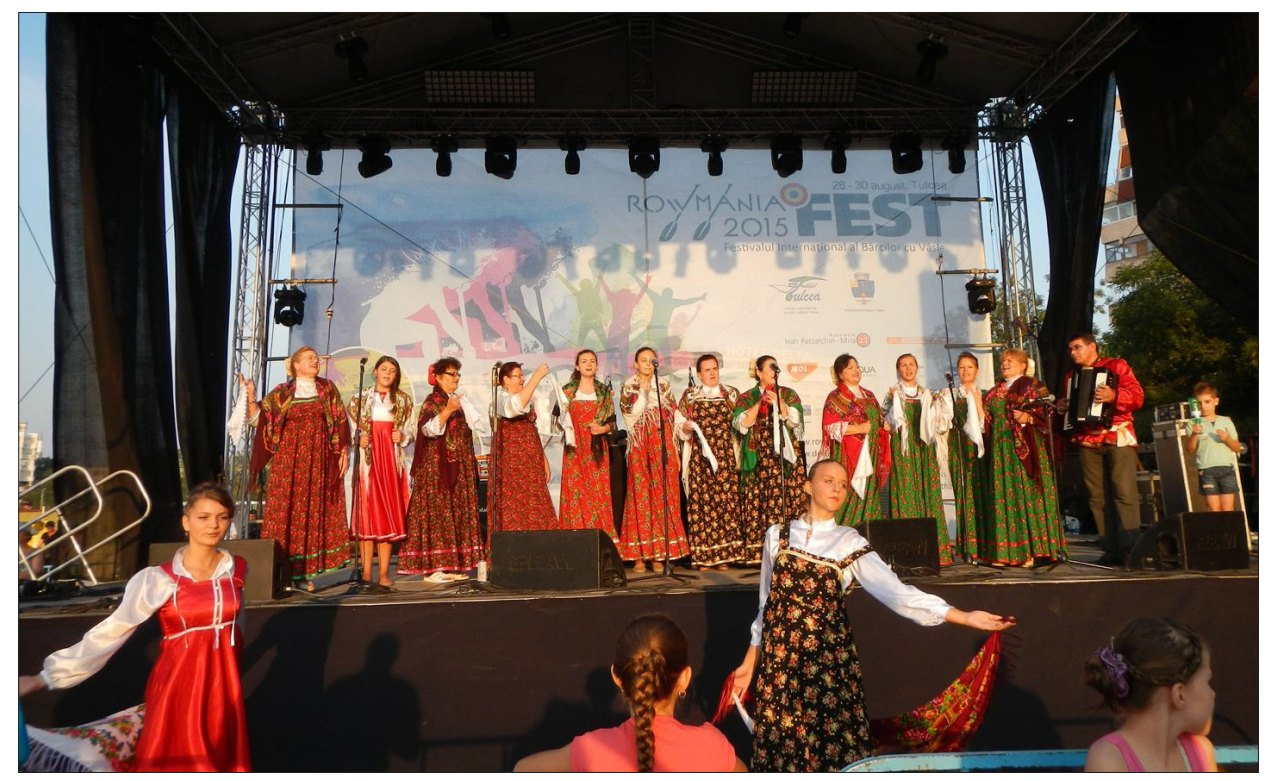

Figure 8. Choir performing in traditional costumes at a festival in Romania. Photograph by Cristina Clopot, Tulcea County, August 2015.

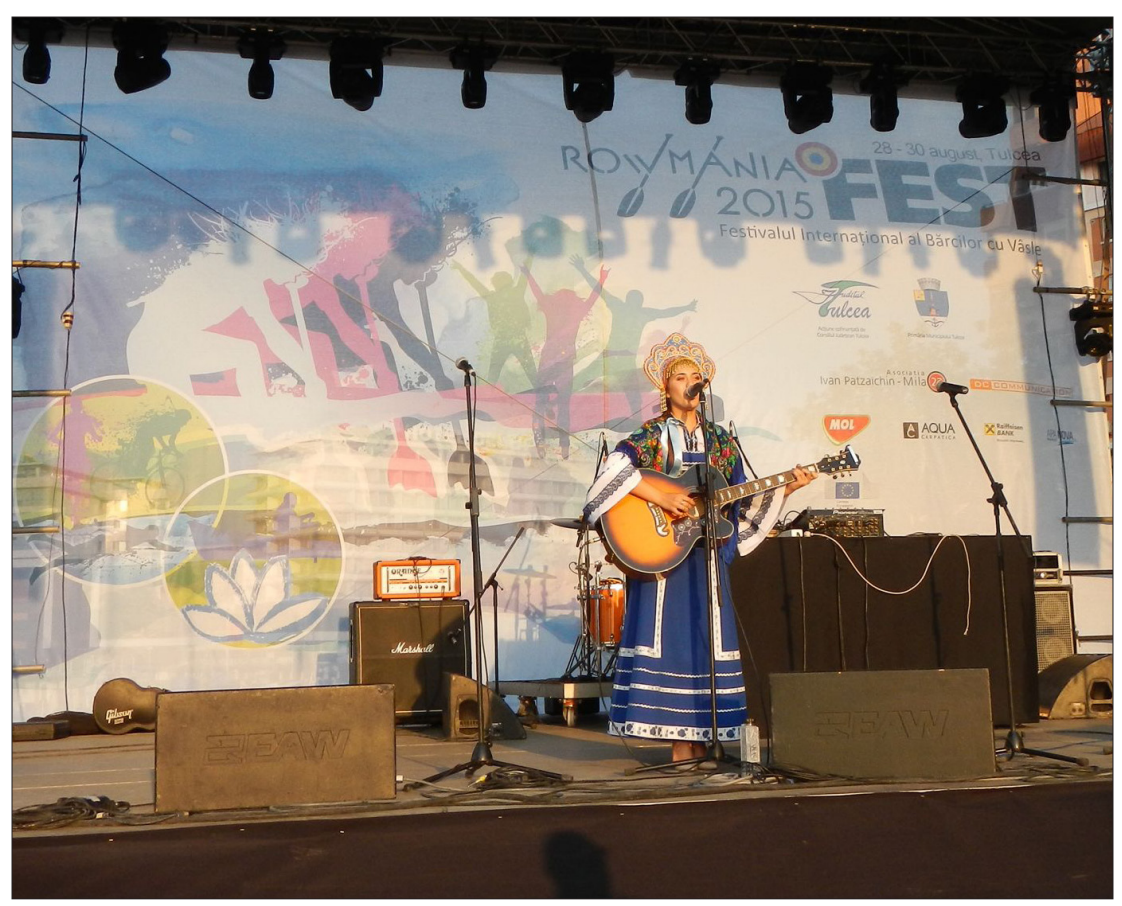

Figure 9. Singer performing on stage, wearing a reconstructed Russian costume with a long dress and a kokoshnik. Photograph by Cristina Clopot, Tulcea County, August 2015. 
such as the National Minorities' Day each December. To the uninformed eye, these elements might as well be traditional, yet other 'innovations' in terms of clothing indicate towards redefinitions of what is traditional. Often performing groups wear large shawls to cover their shoulders, usually models with large flowers, vividly coloured, with tassels. Informants mentioned at times that such objects have traditional Russian models, albeit their labels often mark 'Made in Turkey'. What further elements of constructing a Russian image can be accommodated here?

As Hobsbawm argues, "Traditions' which appear or claim to be old are often quite recent in origin and sometimes invented" (Hobsbawm 1992: 1). One 'traditional' item that drew my attention was the head accessory known as the kokoshnik, an elaborate beaded piece. Such headdresses are also used by performers to express their Russianness. These elements, together with the costumes, are handmade by skilled craftspeople. These pointed items have, at times, elaborate beaded embroidery elements on the rigid arch, while in the front of the item a pattern of crocheted beads covers the forehead, sometimes a couple of beaded threads fall down the sides. The headdress is tied at the back with a lace. Colours vary from monochrome to multicoloured elements. According to available sources, there is little indication such elements were part of the traditional costume of Old Believers originating from the southern part of the Russian Empire, yet fieldwork has shown they have become rather popular. During fieldwork I have seen these elements used in performances in different secular events across the country, either organised by the community or by other institutions.

Can these innovations, especially the last example, be interpreted under the umbrella of Hobsbawm's ideas about the 'invention of tradition' (Hobsbawm 1992)?

Ullrich Kockel (2007: 21) argues that "the defining elements of tradition are not that it is old and unchanged, but that it consists of skills and knowledge handed down in a continuous process and for a continuously meaningful purpose". Moreover, going back to Webb Keane's ideas, semiotic ideologies are contingent on their particular contexts and, as contexts shift, existing repertoires of usage can get changed due to the openness of significations (Keane 2005a).

Problems appear, in my view, when favour shifts from original social use and centuries-old semiotic ideologies to metacultural productions and staging of heritage to suggest Russian ethnicity.

How easily can we differentiate between modern reconstructions and authentic traditions? Maybe the following example from my fieldwork will provide further layers to this argument. When speaking with a female Old Believer about traditional clothing during a secular celebration in a city, she pondered 
on how the religious costume could be perceived as out of place in a cosmopolitan city: "Do you imagine us going around in the city with the kerchiefs on our heads, in our long skirts? I did not know what streets to go on to hide when I went to church in my hometown, let alone here." In such urban places the kerchief is more fashionably worn as a scarf rather than on the head, or as converted into a modern skirt. Commodification brings a new layer to this discussion. Following Nezar AlSayyad, a question is well placed here of what happens when "the image of the thing replaces the thing itself" (AlSayyad 2007: 163). Is that the end of tradition? For him, this should not be equalled to an actual disappearance but "the end of our valuation and perception of it as a reservoir for a meaningful 'authentic past"' (AlSayyad 2007: 165). But that stands in stark contrast to discourses which claim centuries-old continuity. Different layers of innovation, as exemplified earlier, seem to echo what Robert Crummey noted: "Old Belief was a complex combination of groups, institutions and tendencies that changed continually under a rubric of changelessness" (Crummey 1993: 710).

\section{ACKNOWLEDGEMENTS}

The fieldwork for this project was supported by the Estella Canziani PostGraduate Bursary for Research, offered by the Folklore Society.

\section{NOTES}

1 Name changed to protect the identity of the informant.

${ }^{2}$ In the northern part of the country, in the villages that I visited, people name the skirt which has lace ribbon applications as lenta. Although the name stands to represent the lace only originally, in these areas it has become part of the local vernacular language to mark the skirt itself.

\section{REFERENCES}

AlSayyad, Nezar 2007. Consuming Heritage or the End of Tradition: The New Challenges of Globalization. In: Yehuda E. Kalay \& Thomas Kvan \& Janice Affleck (eds.) New Heritage: New Media and Cultural Heritage. London \& New York: Routledge, pp. 155-169. 
Arantes, Antonio A. 2013. Beyond Tradition: Cultural Mediation in the Safeguarding of ICH. In: Arizpe Lourdes \& Cristina Amescua (eds.) Anthropological Perspectives on Intangible Cultural Heritage. Heidelberg: Springer, pp. 39-55. Available at http:// www.springer.com/gp/book/9783319008547, last accessed on October 14, 2016.

Crummey, Robert O. 1993. Old Belief as Popular Religion: New Approaches. Slavic Review, Vol. 52, No. 4, pp. 700-712. http://dx.doi.org/10.2307/2499648.

Druzhelyubov, Vladimir 2007. Schism and Russia's Old Believers. Contemporary Review, Vol. 289, No. 1687, pp. 454-460. Available at http://www.thefreelibrary.com/ Schism+and+Russia's+Old+Believers.-a0174196643, last accessed on October 14, 2016.

Fenoghen, Alexandra \& Fenoghen, Sevastian 2004. Sarichioi, o Enigmă a Secolului XIX. [Sarichioi, a 19th Century Enigma.] Bucharest: Editura Kriterion.

Fenoghen, Sevastian 1998. Sarichioi: Pagini de istorie. [Sarichioi: History Pages.] Bucharest: Editura Kriterion.

Hobsbawm, Eric 1992. Introduction: Inventing Traditions. In: Eric Hobsbawm \& Terence Ranger (eds.) The Invention of Tradition. Cambridge: Cambridge University Press, pp. 1-14. Available at http://faculty.washington.edu/ellingsn/Hobsbawm Inventing_Traditiions.pdf, last accessed on October 14, 2016.

Ipatiov, Filip 2001. Ruşii-lipoveni din România. [Russian-Lipovans from Romania.] Cluj-Napoca: Editura Presa Universitară Clujeană.

Johnson, Patricia White 1983. Dress and Acculturation among the Russian Old Believers in Oregon. Diss. (MA Thesis). Unpublished. University of Oregon, USA. Available at https://ir.library.oregonstate.edu/xmlui/handle/1957/7891, last accessed on October 14, 2016.

Keane, Webb 2003. Semiotics and the Social Analysis of Material Things. Language \& Communication, Vol. 23, pp. 409-425. Available at http://townsendgroups.berkeley. edu/sites/default/files/webb_keane_semiotics_and_things.pdf, last accessed on October 14, 2016.

Keane, Webb 2005a. Signs Are Not the Garb of Meaning: On the Social Analysis of Material Things. In: Daniel Miller (ed.) Materiality. Durham \& London: Duke University Press, pp. 182-205. Available at http://is.muni.cz/el/1423/podzim2015/SOC571/ um/59556777/Keane_Social_Analysis_of_Material_Things.pdf, last accessed on October 14, 2016.

Keane, Webb 2005b. The Hazards of New Clothes: What Signs Make Possible. In: Susanne Küchler \& Graeme Were (eds.) The Art of Clothing. London: UCL Press, pp. 1-16. Available at http://sites.lsa.umich.edu/webbkeane/wp-content/uploads/ sites/128/2014/07/hazards_new_clothes.pdf, last accessed on October 14, 2016.

Kirshenblatt-Gimblett, Barbara 1995. Theorizing Heritage. Ethnomusicology, Vol. 39, No. 3, pp. 367-380. http://dx.doi.org/10.2307/924627.

Kockel, Ullrich 2007. Reflexive Traditions and Heritage Production. In: Ullrich Kockel \& Máiréad Nic Craith (eds.) Cultural Heritages as Reflexive Traditions. Basingstoke, Hampshire \& New York, N.Y.: Palgrave Macmillan, pp. 19-33.

Kuutma, Kristin 2013. Concepts and Contingencies in Heritage Politics. In: Arizpe Lourdes \& Cristina Amescua (eds.) Anthropological Perspectives on Intangible Cultural Heritage. Heidelberg: Springer, pp. 1-15. Available at http://www. springer.com/gp/book/9783319008547, last accessed on October 14, 2016. 
Liashchenko, Marina \& Khriukina, Anna 2006. Pokhoronno-pominal'nyi kompleks. [Funeral and Memorial Ritual Complex.] In: Marina Liashchenko (comp.) Obshchina staroobriadtsev-lipovan Primorsko-Akhtarskogo raiona: istoriia $i$ kul'tura. [The Community of the Old Believers Lipovane from the PrimorskoAkhtarsky District of the Krasnodar Region.] Krasnodar: Nauchno-issledovatel'skii tsentr traditsionnoi kul'tury GNTU “Kubanskii kazachii khor", pp. 79-84. Available at http://russkayasvyaz.ru/doc/lipovane.pdf, last accessed on October 17, 2016.

Meyendorff, Paul 1991. Russia, Ritual and Reform: The Liturgical Reforms of Nikon in the 17th Century. Crestwood, NY: St Vladimir's Seminary Press.

Miller, Daniel 2010. Stuff. Cambridge: Polity Press.

Naumescu, Vlad 2011. The Case for Religious Transmission: Time and Transmission in the Anthropology of Christianity. Religion and Society: Advances in Research, Vol. 2, No. 1, pp. 54-71. http://dx.doi.org/10.3167/arrs.2011.020104.

Parekh, Bhikhu 2007. Reasoned Identities: A Committed Relationship. In: Margaret Wetherell \& Michelynn Laflèche \& Robert Berkeley (eds.) Identity, Ethnic Diversity and Community Cohesion. Los Angeles \& London \& Thousand Oaks \& New Delhi \& Singapore: SAGE, pp. 130-136. http://dx.doi.org/10.4135/9781446216071.

Pascal, Pierre 1963. Avvakum et les debuts du Raskol. Paris: Mouton \& Co.

Pentikäinen, Juha 1999. What is Old Belief? Who are the Starovery? In: Juha Pentikäinen (ed.) "Silent as waters we live". Old Believers in Russia and Abroad: Cultural Encounter with the Finno-Ugrians. Helsinki: Suomalaisen kirjallisuuden seura, pp. 11-27.

Prygarine, Olexandre 2004. Les "vieux-croyants" (Lipovane) du delta du Danube. Ethnologie Française, Vol. 34, No. 2, pp. 259-266. Available at http://www.cairn. info/revue-ethnologie-francaise-2004-2-page-259.htm, last accessed on October 17, 2016.

Turner, Victor W. 1969. The Ritual Process: Structure and Anti-Structure. London: Routledge \& Kegan Paul.

UNESCO 2003 = Convention for the Safeguarding of the Intangible Cultural Heritage. Paris. Available at http://www.unesco.org/culture/ich/en/convention, last accessed on October 14, 2016.

Van Gennep, Arnold 1996. Riturile de trecere. [The Rites of Passage.] Trans. by Nora Vasilescu \& Lucia Berdan. Iasi: Polirom. Available at http://classiques.uqac. ca/classiques/gennep_arnold_van/rites_de_passage/rites_de_passage.pdf, last accessed on October 17, 2016.

Wulff, Helena 2002. Yo-Yo Fieldwork: Mobility and Time in a Multi-Local Study of Dance in Ireland. Anthropological Journal on European Cultures, Vol. 11, pp. 117-136. Available at http://www.jstor.org/stable/43234897, last accessed on October 17, 2016. 